\title{
Do greenhouse experiments predict willow responses to long term flooding events in the field?
}

\author{
¿Los experimentos en invernáculo predicen las respuestas de sauces \\ a períodos largos de inundación a campo?
}

\author{
Teresa Cerrillo a , María E Rodríguez ${ }^{\text {b }}$, Fabio Achinelli ${ }^{b, c}$, Guillermo Doffo ${ }^{b}$, Virginia MC Luquez ${ }^{\text {b* }}$ \\ ${ }^{a}$ EEA INTA Delta, Río Paraná de Las Palmas y Canal Laurentino Comas, Campana, Argentina. \\ *Corresponding author: ${ }^{\mathrm{b}}$ Consejo Nacional de Investigaciones Científicas y Técnicas (CONICET) - \\ Universidad Nacional de La Plata (UNLP), Instituto de Fisiología Vegetal (INFIVE), C.C. 327, (1900), \\ La Plata, Argentina, tel.: 54-221-423-6618, vluquez@agro.unlp.edu.ar \\ ${ }^{c}$ Comisión de Investigaciones Científicas (CIC), Buenos Aires, Argentina.
}

\begin{abstract}
SUMMARY
Flooding tolerance should be included as a trait in breeding programs in forested areas where extreme flooding events lasting several months can occur. In this context, it is difficult to carry out controlled, long-term flooding experiments with big trees due to the large number of specimens to screen. The hypothesis in this work was that a relatively short-term flooding experiment in a greenhouse would be useful to select clones capable of enduring long term flooding events in the field. The survival of 4 willow clones in a long term, 12 years field trial that was subjected twice to long term flooding events, was compared with the survival, growth and gas exchange of those same clones subjected to flooding in the greenhouse for three months. There were differences in flooding survival in the field: clone AN4 showed a $100 \%$ survival, followed by clone 395 (43\%), clone 131-27 (18\%) and clone 13-44 (14 \%). In the greenhouse, all plants survived and only flooded plants of clone 13-44 experienced a statistically significant growth and stomatal conductance reduction. The flood tolerance ranking in the field and in the greenhouse only partially overlapped; the worst clone in the field could be identified in the short-term greenhouse experiment, though the best one could not. It was not possible to identify clones with tolerance to long-term flooding episodes in the field. Nevertheless, the greenhouse results were useful to identify clones showing flooding sensitivity and tolerance to short term flooding episodes.
\end{abstract}

Key words: Salix spp., survival, growth, Paraná River Delta.

\section{RESUMEN}

Es necesario incluir la tolerancia a la inundación como un carácter en programas de mejoramiento para zonas forestadas donde eventos extremos de inundación que pueden durar meses son comunes. En este contexto, es difícil llevar a cabo experimentos controlados de larga duración con árboles de gran tamaño, debido al elevado número de ejemplares que es necesario evaluar. La hipótesis de este trabajo fue que un experimento relativamente corto de inundación en el invernáculo sería útil para seleccionar clones capaces de soportar eventos de inundación de varios meses en el campo. Se comparó la supervivencia de cuatro clones de sauces en un ensayo a campo que experimentó dos episodios largos de inundación a lo largo de 12 años, y la supervivencia, crecimiento e intercambio gaseoso de los mismos clones inundados por tres meses en invernáculo. Se encontraron diferencias en la supervivencia en el ensayo a campo, del clon AN4 sobrevivieron el $100 \%$ de las plantas, seguido por el clon 395 (43\%), clon 131-27 (18\%) y clon 13-44 (14\%). En el invernáculo, todas las plantas sobrevivieron y sólo las plantas inundadas de 13-44 experimentaron una reducción significativa del crecimiento y la conductancia estomática. El ranking de tolerancia en el campo y en invernáculo sólo coincidió parcialmente, el clon menos tolerante en el campo pudo ser identificado en el invernáculo, pero no el clon más tolerante. Si bien no fue posible identificar clones con tolerancia a episodios largos de inundación, los datos del ensayo en invernáculo permitieron identificar clones con sensibilidad a la inundación, y con tolerancia a episodios cortos de anegamiento.

Palabras clave: Salix spp., supervivencia, crecimiento, Delta del Paraná.

\section{INTRODUCTION}

The main area for willow (Salix spp.) plantations in Argentina is the Paraná River Delta. This region can experience episodes of flooding, caused by a combination of factors: high water levels of the Paraná River or its tributaries from the Paraná, La Plata basin, or excessive local rains and storm surge floods caused by southeastern winds over the La Plata River (Borodowski 2006, Luquez et al. 2012). The duration of the flooding episodes can be very variable, from hours to days or months. The short-term flooding episodes usually do not cause severe damage, but the long term flooding events, lasting several months, can cause severe economic losses, including the total loss of forest plan- 
tations. Exceptionally long periods of flooding in the area occur on an irregular pattern; during the twentieth century these episodes occurred in 1905, 1914, 1922, 1940, 1958, 1959, 1966, 1973, 1977, 1982-84, and 1998 (Borodowski 2006). In November 2009, another major flooding episode affected the northern area of the territory, and lasted nearly six months. Climate change models predict an increase in flooding risk during the next decades, due to a higher frequency of excessive local rains and storm surge floods (Barros et al. 2006). In consequence, it is important to breed willow clones that can survive these extreme conditions.

The responses to flooding of woody plants are complex and vary according to species, the age of the tree, whether floodwater is still or running, the degree of covering by water, the moment of the year and the duration of the flooding period (Kozlowski 1997, Crawford 2003, Glenz et al. 2006). Among the responses to flooding in plants, there is growth reduction, stomatal closure, decrease of photosynthetic activity, development of hypertrophied lenticels, adventitious roots and aerenchyma formation, changes in the absorption and availability of mineral nutrients, and several metabolic changes caused by hypoxic or anoxic conditions (Kozlowski 1997, Vartapetian and Jackson 1997, Braendle and Crawford 1999, Glenz et al. 2006, Bailey-Serres and Voesenek 2008, Colmer and Voesenek 2009). In the case of shoots, flood sensitive species experience a reduction in growth through a decrease in leaf formation and expansion (Kozlowski 1997). The photosynthetic leaf area can be further reduced by the acceleration of leaf senescence and abscission (Kozlowski 1997). Regarding root growth, flooding enhances root mortality and the development of a shallow adventitious root system in flood tolerant species (Glenz et al. 2006). The reduction in growth comprises both shoots and roots, but it is more marked in the case of roots, thus decreasing the root/shoot ratio (Kozlowski 1997).

Flooding tolerance is defined as the capacity of woody plants to survive low oxygen conditions (Glenz et al. 2006, Niinemets and Valladares 2006). Survival after a long period of flooding is species-dependent (Terazawa and Kikuzawa 1994, Angelov et al. 1996, Amlin and Rood 2001, Parelle et al. 2007). Swamp-adapted tree species can survive up to two years of continuous root flooding (Angelov et al. 1996), and some trees which grow in seasonally flooded areas such as the Amazonas floodplain are adapted to complete submergence for a long period of time (Parolin 2009). Central European Salix species have been reported as having high tolerance to flooding episodes in the field (Glenz et al. 2006); and in a pond originated from a beaver dam in Montana, they were still alive after 5 years of flooding (Amlin and Rood 2001).

In the Paraná Delta area, flooding events are frequent but do not occur in a seasonal pattern. Periods of flooding can be separated by several years or even decades, as in the case of the extreme flooding events cited above. In an environment with such a risk of flooding, it is important to include flood tolerance as a criterion in breeding programs aimed for the area. It is difficult to carry out controlled, long-term flooding experiments with big sized trees in a breeding program with a large number of specimens to screen. The ideal situation would be to test for flood tolerance in small plants in a relatively short-term controlled flooding experiment, and to be able to use this information to select genotypes that are also tolerant to long-term, extreme flooding events. The hypothesis was that the ranking of flood tolerance of controlled flooding experiments in the field and in the greenhouse would be the same, and that the information obtained in the greenhouse experiments with relatively short-term flooding periods would be useful to select clones capable of enduring extreme flooding events in the field.

\section{METHODS}

Field trial measurements. Information about the clones used in both field and greenhouse experiments is detailed in table 1 . The field trial was originally intended to evaluate productivity of willow clones, at Establecimiento Las Ánimas, Papel Prensa, Arroyo Martínez, Ibicuy Islands, province of Entre Ríos, Argentina (longitude 58 $24^{\circ}$ W, latitude $\left.33^{\circ} 38^{\prime} \mathrm{S}\right)$. Cuttings of $0.90 \mathrm{~cm}$ long were planted on August $14^{\text {th }}$, 1991, in a completely randomized block design, with four replicates and 25 plants per plot. The plots were rectangular, with a total size of 17.5 x $10 \mathrm{~m}$.

The field trial experienced two prolonged periods of flooding: the first period, in 1992, when the plantation was one year old, lasting five months; and the second, in 1998, when the plantation was seven years old, lasting 14 months. In the latter, the stagnant water reached a maximum level of $1.5 \mathrm{~m}$, at this point the height of the trees was about $20 \mathrm{~m}$, and in consequence they were only partially covered by water. Plant survival was evaluated twice by counting the number of living plants per plot. The first evaluation was at the end of the first year, before the first flooding episode took place; the survival of the plantation was very high: $100 \%$ for clone SN4, 99\% for clone 395, $97 \%$ for clone $131-27$ and $100 \%$ for clone $13-44$. When the plantation was 12 years old, plant survival was evaluated as indicated above. Additionally, it was recorded whether the stem of the surviving plants originated from the original cutting, or if the original stem died back and a new stem sprouted and replaced it.

Greenhouse experiment. For the greenhouse experiment, one year old cuttings of $50 \mathrm{~cm}$ in length were obtained from stool beds and stored at $4{ }^{\circ} \mathrm{C}$ until planted in $4.5 \mathrm{~L}$ pots filled with soil. The planting date was August $7^{\text {th }}$, 2009. The pots were placed in a greenhouse at INFIVE, La Plata, Argentina, in a completely randomized design with six replicates for each clone and treatment, and with a border row which was not used for measurement. Plants were watered to keep the soil at field capacity until the 
Table 1. Detail of the Salix genotypes included in this study. The country indicated is where the selection or cross took place. Detalle de los genotipos de Salix incluidos en este trabajo. El país indicado es aquél dónde tuvo lugar la selección o cruzamiento.

\begin{tabular}{llll}
\hline Complete clone name & Abbreviation & Species / Hybrid & Origin \\
\hline 'Alonzo nigra 4 INTA' & AN4 & Salix nigra Marsh. & $\begin{array}{l}\text { Open pollinated (mother selected from seeds } \\
\text { introduced in 1961 from the US). Country: } \\
\text { Argentina }\end{array}$ \\
'Ragonese 131-27 INTA' & $131-27$ & Salix babylonica L. x Salix alba L. & $\begin{array}{l}\text { Controlled cross (1957) } \\
\text { Country: Argentina }\end{array}$ \\
'Barrett 13-44 INTA' & $13-44$ & Salix matsudana Koidz. x Salix alba L. & $\begin{array}{l}\text { Controlled cross (1969) } \\
\text { Country: Argentina }\end{array}$ \\
'395-112' & 395 & Salix babylonica L. x Salix alba L. & $\begin{array}{l}\text { Controlled cross (1965) } \\
\text { Country: Argentina }\end{array}$ \\
\hline
\end{tabular}

beginning of the stress treatment. Irradiance inside the greenhouse on clear days reached a maximum value of 1,228 $\mathrm{mmol} \mathrm{m} \mathrm{m}^{-2}$. Bud flush occurred in most clones between August $15^{\text {th }}$ and August $30^{\text {th }}$, but in AN4 it was delayed until the first week of September. After sprouting and before starting the treatment, a slow-release commercial fertilizer (NPK 12:5:14 plus Mg, S, Ca, Zn, Fe, Mo and B) was added to the pots to ensure an adequate nutrient availability. The dose was $1 \mathrm{~g}$ of fertilizer per pot, and the fertilization treatment was repeated twice. To avoid pest and diseases, the saplings were treated with an insecticide (o,s dimethyl-acethyl phosphoroamydotiathe) and fungicides (Carbendazim $50 \% \mathrm{SC}$ ). Before the beginning of the flooding treatment, trees were pruned to one shoot per plant, in order to minimize the variability induced by different number of shoots per tree. Flooding was induced when the shoots were $60 \mathrm{~cm}$ long by placing the potted trees inside a sealed $7 \mathrm{~L}$ pot filled with tap water up to approximately $10 \mathrm{~cm}$ above soil level; water was added when necessary to keep this level. The type of applied flooding stress is of common occurrence in the Paraná Delta area, with only roots and part of the shoots covered by stagnant floodwater. The flooding stress treatment started on October $14^{\text {th }}, 2009$, and lasted three months. Plants were actively growing during the period when the flooding stress occurred, comprising the spring and beginning of summer in the Southern Hemisphere.

Greenhouse experiment measurements. Total shoot height (height, $\mathrm{cm}$ ) was measured with a ruler, and basal diameter (diameter, mm) was measured with a digital caliper. Volume index (VI, in $\mathrm{cm}^{3}$ ) was calculated as follows:

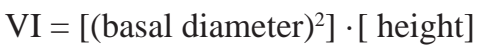

At the beginning of the experiment, the last completely expanded leaf was tagged with a colored wire, and all leaves longer than $2 \mathrm{~cm}$ were counted every week, to calculate the cumulative number of new developed leaves. Dry weight of leaves, stem and roots was determined at the end of the experiment, drying them at $65^{\circ} \mathrm{C}$ until cons- tant weight was reached. Adventitious root formation and other morphological alterations were observed throughout the experiment. Total leaf area $\left(\mathrm{cm}^{2}\right)$ was measured at the end of the experiment with a LICOR LI 3100 leaf area meter. Individual leaf area $\left(\mathrm{cm}^{2}\right)$ and specific leaf area $\left(\mathrm{cm}^{2}\right.$ $\mathrm{g}^{-1}$ ) were measured on the latest fully expanded leaf, at the end of the experiment. Stomatal conductance was measured with a Decagon SC1 porometer, in the abaxial side of the latest fully expanded leaf. Measurements were carried out without any artificial light supplement, between $11.30 \mathrm{am}$ and $01.30 \mathrm{pm}$, the average irradiance during those measurements being $928 \mathrm{mmol} \mathrm{m}^{-2} \mathrm{~s}^{-1}$. Oxygen diffusion rate (ODR) measurements were carried out using an ODR-meter (Biocontrol, Buenos Aires) according to the manufacturer's instructions.

Statistical analyses. All statistical analyses were carried out with R software version 2.13.0 (R Development Core Team 2012). ANOVA and mean test were carried out using the agricolae package. Height data were transformed to logarithm to meet ANOVA requirements.

\section{RESULTS}

Survival and growth in the field. The survival at the $12^{\text {th }}$ year of planting was clearly different among 4 clones (figure $1 \mathrm{~A}$ and $1 \mathrm{~B})$. Survival, expressed either as the percentage of live plants per plot or as live plants per plot, was the highest for AN4 (100\%), intermediate for clone 395 (43\%), and the lowest for 131-27 (18\%) and for 13-44 $(14 \%)$. AN4 not only differed from the other clones in its survival rate, but also in the fact that it kept its original stem. The surviving plants of clones 395, 131-27 and 13-44 were the product of re-sprouting, since the original stems (i.e., those originating in the cutting during the year of planting) were dead. As a consequence growth was reduced; the average height of AN4 was $18 \mathrm{~m}$, while the average height of the other clones ranged between 5-8 $\mathrm{m}^{1}(1)$.

1 T Cerrillo, personal observation. 

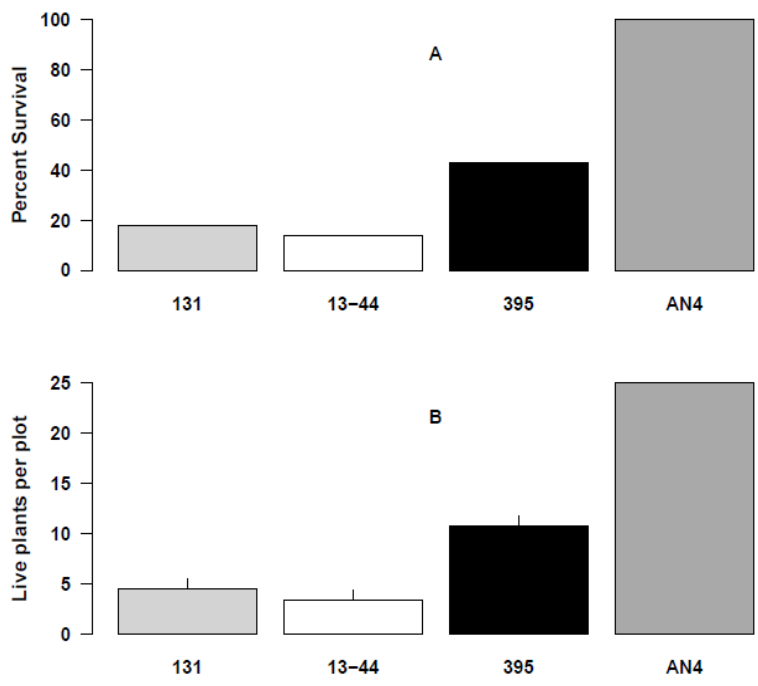

Figure 1. Survival, as the percentage of live plants per plot in a willow field trial subjected to two flooding events, the first when the plantation was one year old, lasting for five months, and the second when the plantation was seven years old for 14 months. Panel A: Survival expressed as percentage. Panel B: survival expressed as number of live plants per plot. Vertical bars: standard error of the mean. Survival was recorded when the plantation was 12 years old. Supervivencia, como porcentaje de plantas vivas por parcela, en un ensayo a campo de sauces que experimentó dos episodios de inundación. El primer episodio ocurrió al año de plantación, y duró 5 meses, el segundo episodio ocurrió a los 7 años de plantación, y se prolongó por 14 meses. Parte A: supervivencia expresada como porcentaje. Parte B: supervivencia expresada como número de plantas vivas por parcela. Barras verticales: error estándar de la media. La supervivencia se determinó cuando la plantación tenía 12 años de edad.

Growth and stomatal conductance measurements in the greenhouse experiment. Oxygen diffusion rate values differed between the two treatments, in control pots the average value of $\mathrm{O}_{2}$ was $31 \mathrm{mg} \mathrm{cm}^{-2} \mathrm{~min}^{-1}(\mathrm{SE} \pm 6.6)$, while in flooded pots it was $5 \mathrm{mg} \mathrm{cm}^{-2} \mathrm{~min}^{-1}(\mathrm{SE} \pm 0.7$ ).

The height of the main stem was measured on a weekly basis from the beginning until the end of the experiment (figure 2). There were not significant differences between control and flooded plants in AN4, 395 and 131-27, while in 13-44 there were significant differences from day 49 onwards. Between days 43 and 69, there was no growth in height in flooded plants of 13-44; growth resumed after day 69 but the plants lagged behind the controls.

Similar results were found on the cumulative number of leaves (figure 3); this is an index of apical activity, since the production and expansion of new leaves are affected by flooding stress (Kozlowski 1997). Between days 35 and 60 the production of new leaves ceased in flooded plants of clone 13-44, starting again and continuing thereafter. There was no significant effect of flooding on the apical activity of the other clones which continued to develop new leaves at the same rate as control plants.

The final growth expressed as Volume Index (figure 4) showed a significant decrease only in flooded plants of
13-44, while in the other clones there was no difference between control and flooded treatments.

Total leaf area (figure 4) was significantly lower in flooded plants of 13-44, whereas in the other clones there were not significant differences between treatments. The individual leaf area (figure 4) showed a similar trend to the total leaf area, flooded plants of clone 13-44 had a significant reduction compared to control plants, but the other clones did not. The specific leaf area (figure 4) was significantly reduced in flooded plants of clones 13-44 and 131-27, though not in 395 or AN4.

The original root system of the flooded plants of all clones died and developed a shallow adventitious root system from the third week of flooding onwards: these roots originated from hypertrophied lenticels in the cutting. The root biomass data presented in this work correspond to these newly developed adventitious roots.

The root/shoot ratio was reduced by flooding in all clones (figure 5). In clone 131-27, the root/shoot ratio was $38 \%$ lower in flooded plants than in control plants, in 13 44 the reduction was $23 \%, 27 \%$ in 395 and $18 \%$ in AN4. Dry matter partitioning between control and flooded plants did not show a significant change except for clone 131-27.

The stomatal conductance (figure 6) was measured several times on the latest expanded leaf. In 13-44, the reduction in stomatal conductance in flooded plants coincided with the period of growth reduction (figures 2 and 3). On some dates there were significant differences between control and flooded plants in clones 395 and 131-27, but no consistent pattern was identified by the growth data as in 13-44.

\section{DISCUSSION}

The responses to flooding of the 4 willow clones in the field were very different. It was clear that AN4, a Salix nigra clone, outperformed all the other clones under extreme flooding conditions, all the plants survived (figures $1 \mathrm{~A}$ and 1B). These results are consistent with previous findings, indicating that the black willow is a flood tolerant species (Carpenter el al. 2008). Because of this quality, Salix nigra is a pioneer in recently developed bottomland forest communities, replaced later in the succession by other tree species (Kozlowski 2002), and it is planted for stream bank stabilization along rivers in North America (Li et al. 2005).

Another important point is the fact that AN4 kept its original stem, while the survivors of the other clones resprouted. This fact may be related to the causes of mortality; whether the death of trees was a direct consequence of the flooding stress, or an indirect result. For example, flooding may cause a general weakening of the individuals, increasing susceptibility to pathogens. This question needs further exploration.

When considering productivity in a plantation that has been flooded for an exceptionally long period of time, survival becomes the most important issue. Growth will always be reduced or even stopped by flooding, but the important 

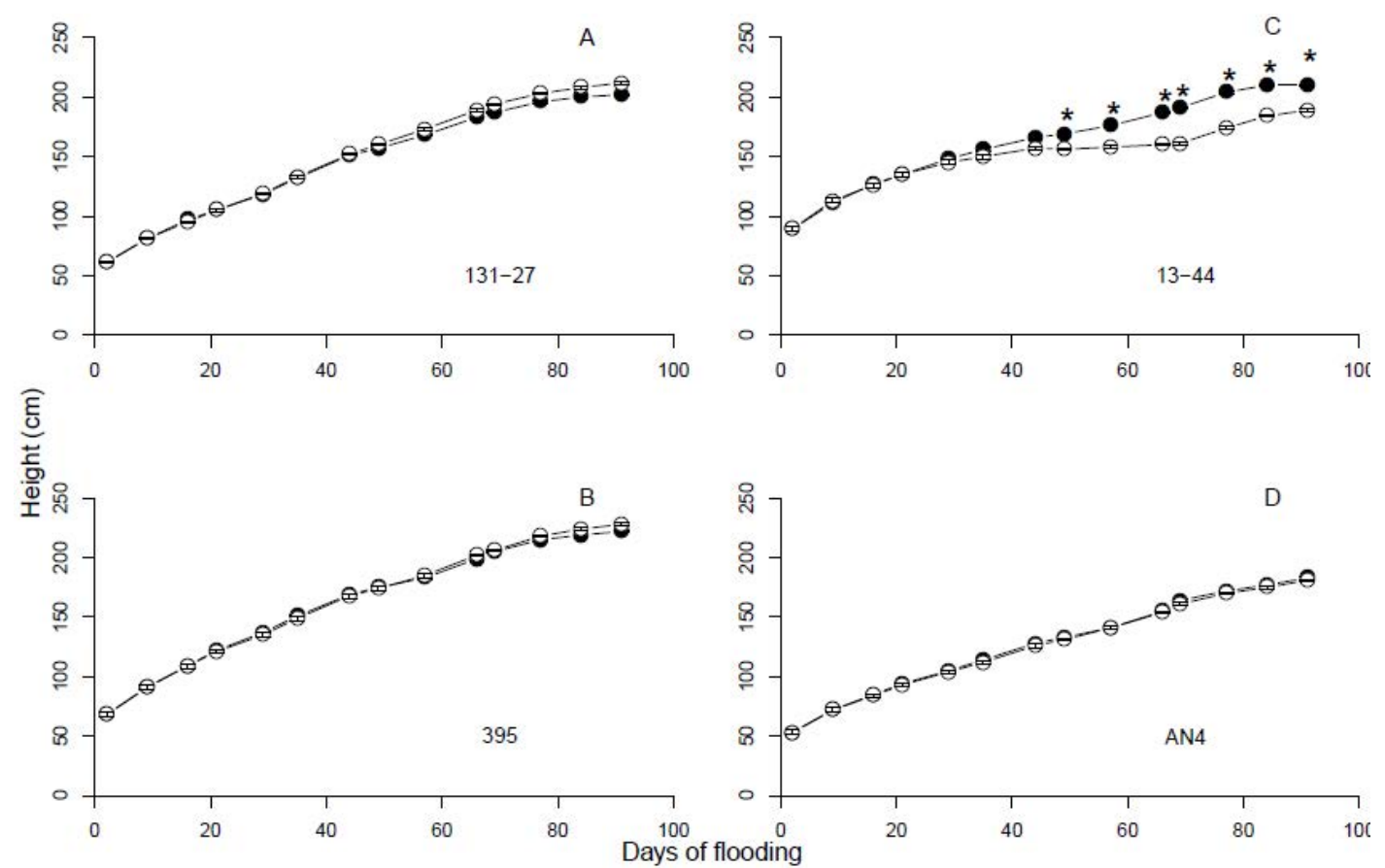

Figure 2. Growth in height of four willow clones during a three-month period flooding experiment in the greenhouse. Non-flooded (control): black circles, flooded: white circles. Asterisks indicated significant differences between the flooded and non-flooded plants of a clone (LSD $5 \%, \mathrm{n}=6$ ). Vertical bars: standard error of the mean.

Crecimiento en altura de cuatro clones de sauce sometidos a un período de inundación de tres meses en invernáculo. Tratamiento control (no inundado): círculos negros; tratamiento inundado: círculos blancos. Los asteriscos indican diferencias significativas entre las plantas controles e inundadas del mismo clon (LSD $5 \%, \mathrm{n}=6$ ). Barras verticales: error estándar de la media.
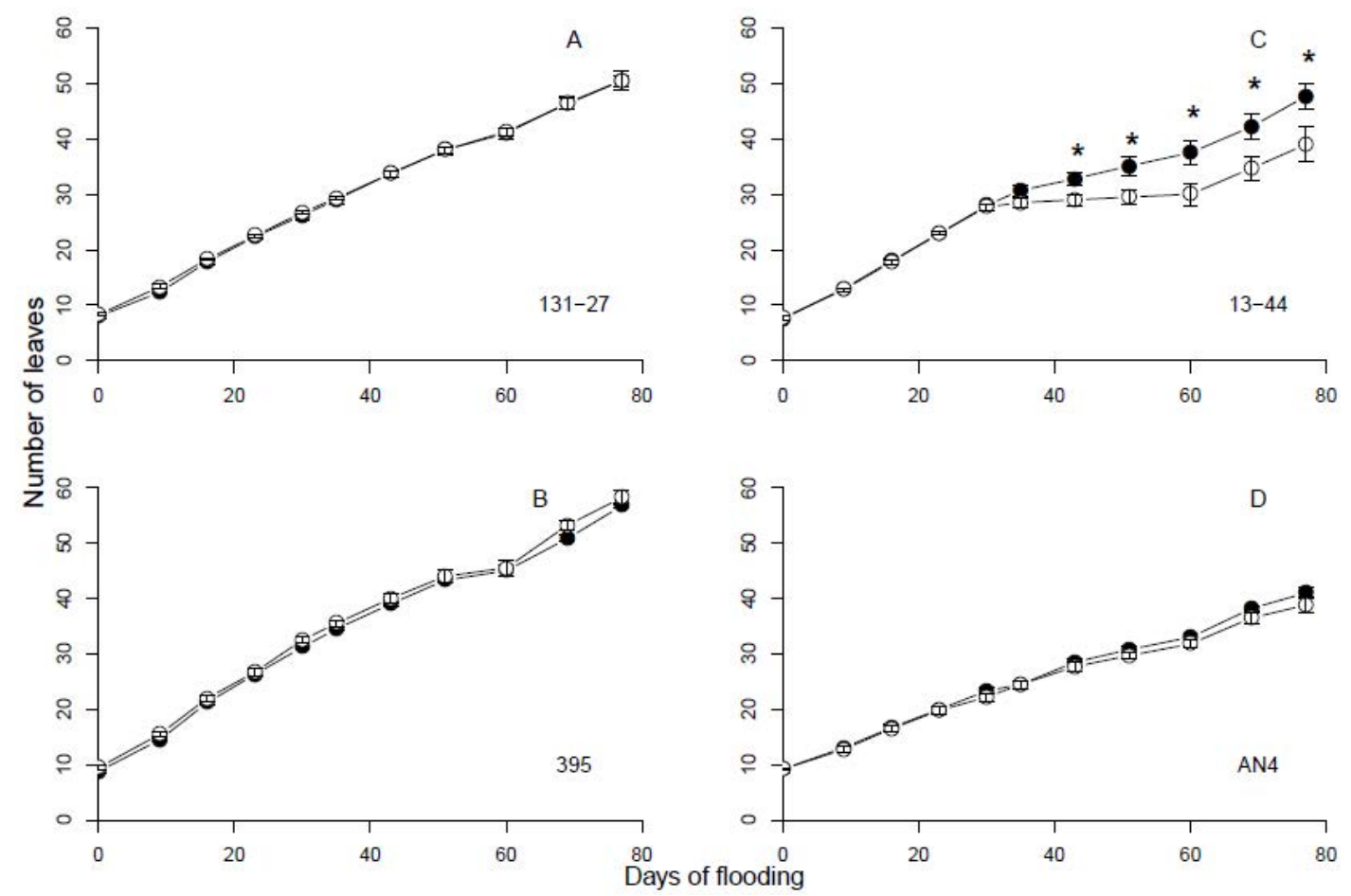

Figure 3. Number of new leaves in four willow clones during a three-month period flooding experiment in the greenhouse. Nonflooded (control): black circles, flooded: white circles. Asterisks indicated significant differences between the flooded and non-flooded plants of a clone (LSD $5 \%, \mathrm{n}=6$ ). Vertical bars: standard error of the mean.

Número de nuevas hojas producidas por cuatro clones de sauce sometidos a un período de inundación de tres meses en invernáculo. Tratamiento control (no inundado): círculos negros; tratamiento inundado: círculos blancos. Los asteriscos indican diferencias significativas entre las plantas controles e inundadas del mismo clon (LSD $5 \%, \mathrm{n}=6$ ). Barras verticales: error estándar de la media. 

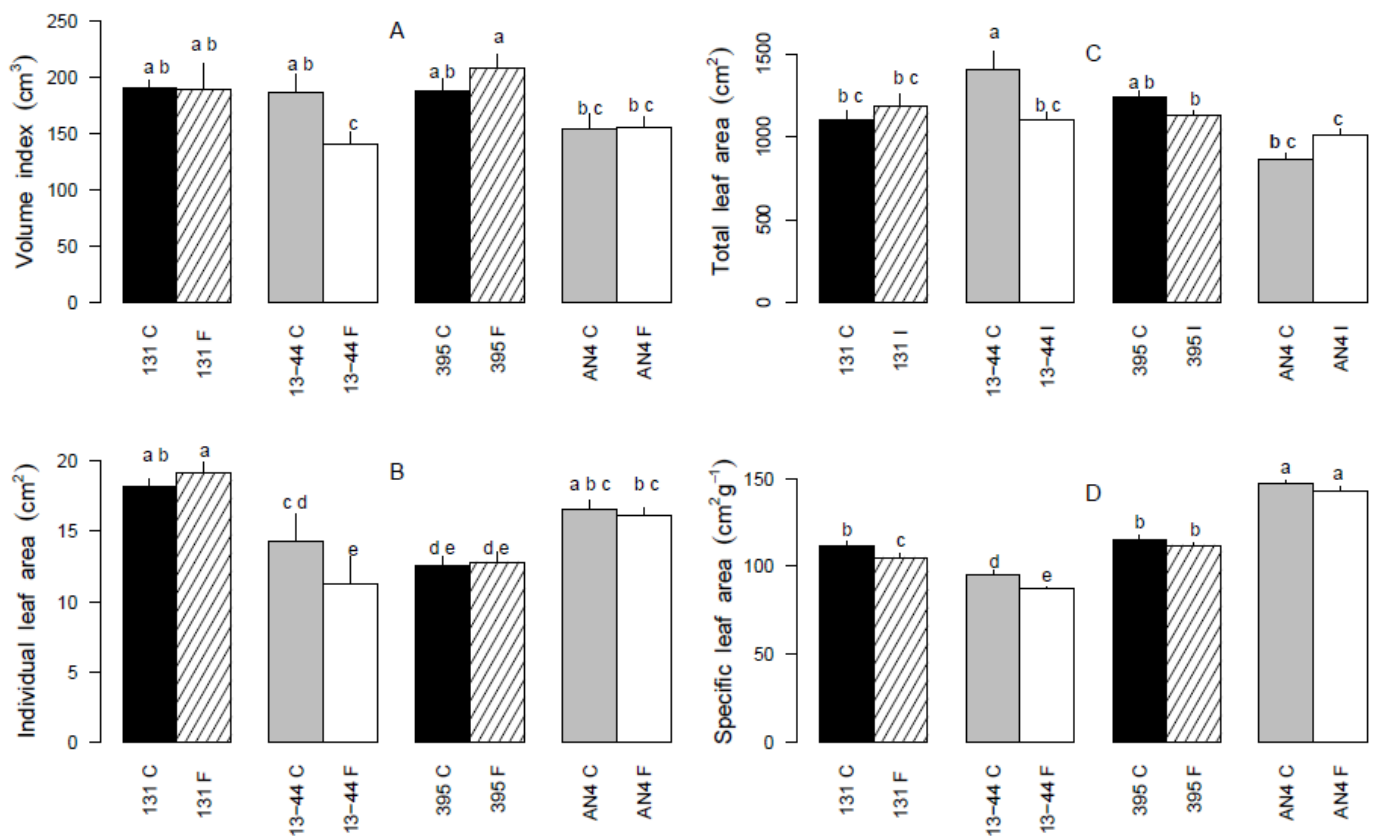

Figure 4. Volume index, total leaf area, individual leaf area, and specific leaf area in four willow clones during a three-month period flooding experiment in the greenhouse. C: Non-flooded, control; F: flooded. Means followed by the same letter do not differ significantly (LSD $5 \%, n=6)$. Vertical bars: standard error of the mean.

Índice de volumen, área foliar total, área foliar individual y área foliar específica en cuatro clones de sauce sometidos a un período de inundación de tres meses en invernáculo. Tratamiento control (no inundado): círculos negros; tratamiento inundado: círculos blancos. Medias seguidas de la misma letra no difieren significativamente (LSD $5 \%, \mathrm{n}=6)$. Barras verticales: error estándar de la media.

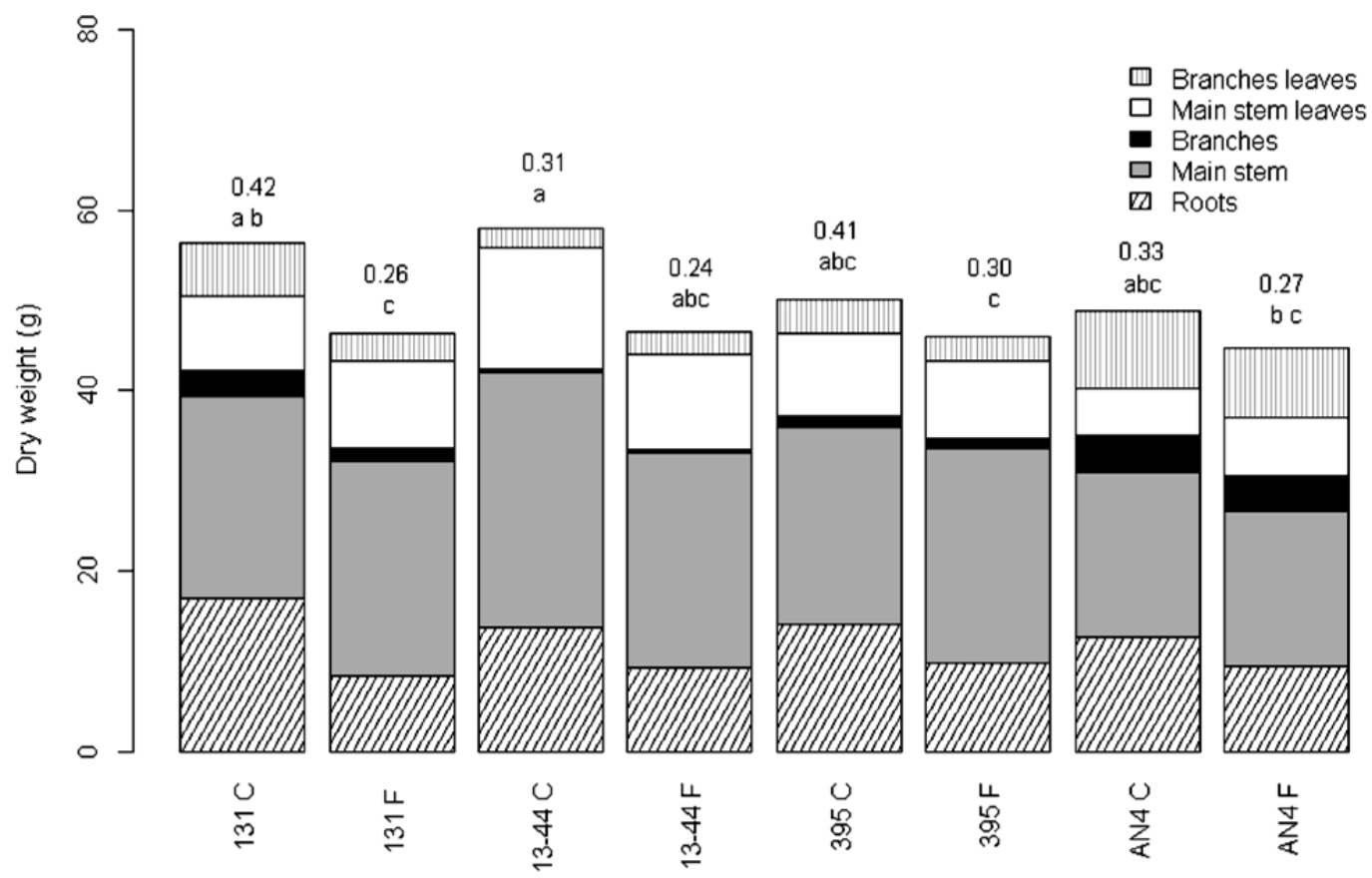

Figure 5. Dry matter partitioning in four willow clones during a three-month period flooding experiment in the greenhouse. C: Nonflooded, control; F: flooded. In italics: root/shoot ratio. Means followed by the same letter do not differ significantly $($ LSD $5 \%$, $n=6)$ for the total dry weight. The leaves were divided between those belonging to the main stem and those from the branches.

Partición de la material seca en cuatro clones de sauce sometidos a un período de inundación de tres meses en invernáculo. Tratamiento control (no inundado): círculos negros; tratamiento inundado: círculos blancos. Las medias seguidas de la misma letra no difieren significativamente (LSD $5 \%, n=6)$ para el peso seco total. En itálica: relación raíz/parte aérea. Barras verticales: error estándar de la media. Las hojas fueron separadas entre aquellas pertenecientes al tallo principal y las hojas pertenecientes a las ramas laterales. 


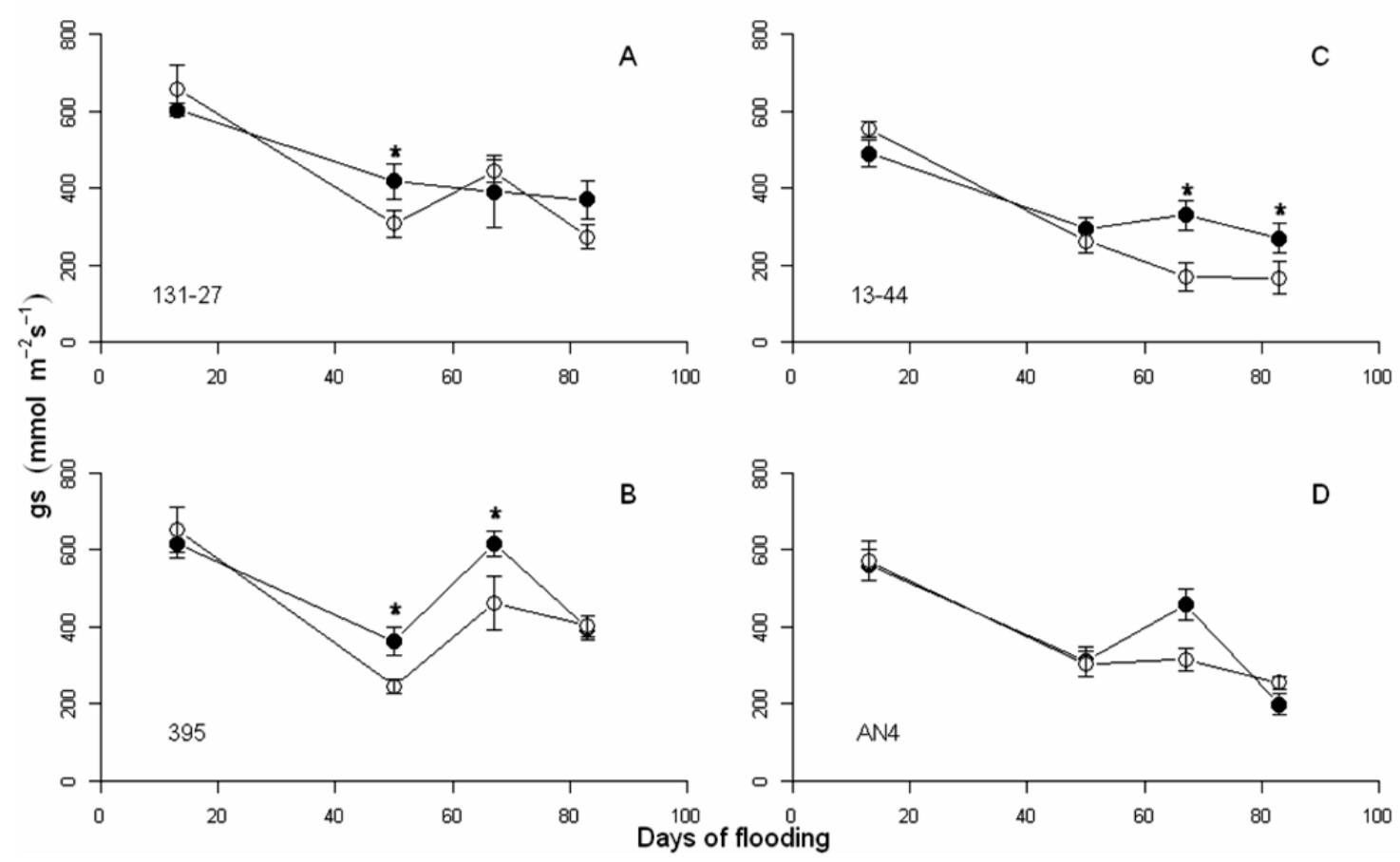

Figure 6. Stomatal conductance (gs) in four willow clones during a three-month period flooding experiment in the greenhouse. Nonflooded (control): black circles, flooded: white circles. Asterisks indicated significant differences between the flooded and non-flooded plants of a clone (LSD $5 \%, \mathrm{n}=6)$. Vertical bars: standard error of the mean.

Conductancia estomática (gs) en cuatro clones de sauce sometidos a un período de inundación de tres meses en invernáculo. Tratamiento control (no inundado): círculos negros; tratamiento inundado: círculos blancos. Los asteriscos indican diferencias significativas entre las plantas controles e inundadas del mismo clon (LSD $5 \%, \mathrm{n}=6$ ). Barras verticales: error estándar de la media.

question is if the tree survives and is able to resume growth after the end of the stress episode. In this situation, foresters will need to wait for more years to cut down the plantation, because of the reduced growth, but the economic loss will never be similar to the total loss of the plantation.

In the greenhouse experiment lasting three months, the flooded plants of all clones survived and developed a shallow adventitious root system. In all clones, the root/shoot ratio was reduced, implying a greater allocation of resources to shoot and a reduction in root biomass. In the flooded plants, these roots were newly formed, adventitious roots, since their original root system died.

Growth was not significantly reduced in flooded plants compared to their controls in clones AN4, 131-27 and 395, either measured for height (figure 2), number of new leaves (figure 3), volume index, total leaf area or individual leaf area (figure 4), while all these variables were significantly reduced in clone 13-44. In addition to that, stomatal conductance was reduced in flooded plants of 13-44 (figure 6). These results are consistent with previous findings that flood tolerant species maintain a higher growth (Angelov et al. 1996) and a higher stomatal conductance than those kept by flood sensitive species (Pezeshki 1993, Sun et al. 1995). From these results, 13-44 can be defined as flood sensitive, while all the other clones are tolerant to relatively short-term flooding. Consistently with field re- sults, 13-44 showed a higher flooding sensitivity than that shown by the other clones, but AN4 did not differ from 131-27 and 395 in terms of growth reduction and gas exchange in the greenhouse.

Amlin and Rood (2001) described observations of flooding survival for adult willows and cottonwoods (Populus spp.) in a pond generated by a beaver dam in Montana. After five years of inundation, the cottonwoods were dead, while willows were still alive. The same authors carried out a flooding greenhouse experiment with genus Populus and Salix saplings; after 152 days of inundation, cottonwoods experienced a higher growth reduction than that experienced by the most flood tolerant willows, and henceforth results regarding cottonwoods-willows comparison were consistent between the field and the greenhouse. These data are difficult to compare with our results as the authors did not quantify the survival of each species; they just assessed that all Рориlus spp. were dead and all survivors were Salix spp. They did not asses if there were differences in survival rate between the different Salix species, or whether the live specimens were the result of re-sprouting, as we did in our work.

There are several reasons to explain why the results in the field and the greenhouse were not exactly similar. One obvious difference was the age of the trees; it can affect different functional aspects of a species including stress tolerance (Niinemets and Valladares 2006). Most 
physiological studies of stress tolerance are carried out in juveniles and not in adult trees, and the knowledge of the ontogenic changes in stress tolerance is fragmentary (Niinemets and Valladares 2006). In addition to the possible ontogenic changes in stress tolerance, in our study flooding conditions were different. In the greenhouse the stress situation occurred during the growing season, while in the field the period of flooding was longer and comprised both the growing and non-growing seasons; in consequence, different responses can be expected (Crawford 2003, Colmer and Voesenek 2009). In spite of these differences, an important result was that the clone with highest flood sensitivity (13-44) could be clearly identified in both situations, either as the one with lower survival in the field or the highest growth reduction in the greenhouse. With the greenhouse experiment it was not possible to identify the clone AN4 that showed the highest survival in the field. To achieve this goal, probably a longer period of flooding would have been necessary. On the other hand, clones with tolerance to up to three months of partial flooding can be identified in the greenhouse experiment, even if they might not be tolerant to exceptionally long flooding periods of more than one year, such as AN4.

In view of these results, it is possible to speculate that the mechanisms to adjust to short-term flooding are different from those that allow survival under extreme flooding conditions. All clones developed an adventitious root system in greenhouse conditions, in spite of their differences in growth or survival under flooding, so the development of a shallow root system, widely regarded as a flood- tolerance trait, is just a part of the whole plant adjustment to the stressful condition.

\section{CONCLUSIONS}

The original hypothesis was not fully validated. The flood tolerance ranking in the field and the greenhouse only partially overlapped, the short-term greenhouse experiment identified the worst clone in the field but failed to do the same with the best one. In view of these results, caution is required when extrapolating results from the greenhouse to the field.

A possible working strategy, for a breeding program with a large progeny to screen, could be to analyze first a large number of individuals in short-term flooding experiments, discarding the worst ones, and afterwards to test the best individuals in a long-term flooding experiment. AN4 can be used as a source for flood tolerance in breeding programs for genotypes aimed at areas with a risk of extreme flooding events.

\section{ACKNOWLEDGEMENTS}

Our thanks to Willow Breeding Program of INTA (VMCL), CONICET, fellowship from ANPCyT (MER). Field experiments were funded by INTA, with partial support of Papel Prensa S.A (TC).

\section{REFERENCES}

Amlin NA, SB Rood. 2001. Inundation tolerances of riparian willows and cottonwoods. Journal of the American Water Resources Association 37(6): 1709 - 1720.

Angelov M, SJS Sung, RL Doong, WR Harms, PP Kormanik, CC Black. 1996. Long and short-term flooding effects on survival and sink-source relationships of swamp-adapted tree species. Tree Physiology 16(5): 477 - 484.

Barros V, A Menéndez, C Natenzon, R Kokot, J Codignotto J, M Re, P Bronstein, I Camilloni, S Ludueña, S González, D Ríos. 2006. Vulnerability to floods in the metropolitan area of Buenos Aires under future climate change. AIACC Working Papers No 26. Consulted Nov. 8, 2010. Available in: http://www.aiaccproject.org/working_papers/working_papers.html

Bailey-Serres J, LACJ Voesenek. 2008. Flooding stress: Acclimations and genetic diversity. Annual Review of Plant Biology 59: 313-339.

Borodowski E. 2006. Álamos y sauces en el Delta del Paraná: situación del sector y silvicultura. Actas de las Jornadas de Salicáceas 2006. Consulted Nov. 10, 2010. Available in:

http://www.sagpya.gov.ar/new/00/forestacion/biblos/JS\%20 2006/pdf\%20tt/Borodowski.pdf

Braendle R, RMM Crawford. 1999. Plants as amphibians. Perspectives in Plant Ecology, Evolution and Systematics 2/1: 58-78.

Carpenter LT, SR Pezeshki, FD Shields Jr. 2008. Responses of nonstructural carbohydrates to shoot removal and soil moisture treatments in Salix nigra. Trees 22(5): 737 - 748.

Colmer TD, LACJ Voesenek. 2009. Flooding tolerance: suites of plants traits in variable environments. Functional Plant Biology 36(8): 665-681.

Crawford RMM. 2003. Seasonal differences in plants responses to flooding and anoxia. Canadian Journal of Botany 81(12): 1224-1246.

Glenz C, RX Schlaepfer, I Iorgulescu, F Kienast. 2006. Flooding tolerance of Central European tree and shrub species. Forest Ecology and Management 235(1-3): 1-13.

Kozlowski TT. 1997. Responses of woody plants to flooding and salinity. Tree Physiology Monograph No 1. Consulted Jan. 15, 2013. Available in: http://www.pucrs.br/fabio/fisiovegetal/Encharcamento.pdf

Kozlowski TT. 2002. Physiological-ecological impacts of flooding on riparian forest ecosystems. Wetlands 22(3): 550561.

Li S, LT Martin, SR Pezeshki, FD Shields. 2005. Responses of black willow (Salix nigra) cuttings to simulated herbivory and flooding. Acta Oecologica 28(2): 173 - 180.

Luquez VMC, F Achinelli, S Cortizo. 2012. Evaluation of flooding tolerance in cuttings of Populus clones used for forestation at the Paraná River Delta, Argentina. Southern Forest 74(1): 61-70.

Niinemets U, F Valladares. 2006. Tolerance to shade, drought and waterlogging of temperate northern hemisphere trees and shrubs. Ecological Monographs 76(4): 521-547.

R Development Core Team. 2012. R: A language and environment for statistical computing. R Foundation for Statistical Computing, Vienna, Austria. ISBN 3-900051-07-0. Consulted March 26, 2012. Available in: http://www.Rproject.org 
Parelle J, O Brendel, Y Jolivet, E Dreyer. 2007. Intra and interespecific diversity in the response to waterlogging of two co-ocurring white oak species (Quercus robur and Quercus patraea). Tree Physiology 27(7): 1027 - 1034.

Parolin P. 2009. Submerged in darkness: adaptation to prolonged submergence by woody species of the Amazonian Floodplains. Annals of Botany 103(3): 359-376.

Sun OJ, GB Sweet, D Whitehead, GD Buchan. 1995. Physiologi- cal responses to water stress and waterlogging in Nothofagus species. Tree Physiology 15(10): 629 - 638.

Terazawa K, K Kikuzawa. 1994. Effects of flooding on leaf dynamics and other seedlings responses in flood-tolerant Alnus japonica and flood-intolerant Betula platyphyla var. japonica. Tree Physiology 14(3): 251 - 261.

Vartapetian BB, MB Jackson. 1997. Plant adaptations to anaerobic stress. Annals of Botany 79 (Supplement A): 3 - 20.

Recibido: 29.03.12

Aceptado: 26.12.12 
